\title{
[討議・回答］
}

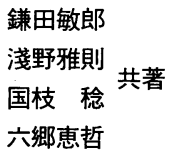

\section{「コンクリート表層欠陥部の定量的非破壊検査 への打音法の適用」への討議・回答}

\author{
（土木学会論文集，No. $704 ／ \mathrm{~V}-552002$ 年 5 月掲載）
}

討議者 (Discussion)

大津政康（熊本大学）

Masayasu OHTSU

\section{1.はじめに}

本論文は, トンネル・ライニングコンクリートの剝 落事故以来, 非常に活発に研究が進められている「打 音法」について, 定量的な取り扱いと数值解析による 解析的な検討を行った貴重な研究成果をまとめたもの である.したがって有用性も高く, 今後の展開へ波及 効果も大きいと考えられる。その意味で研究成果など の内容について明確にすべき点については, この分野 の牽引車としての責務は大きいと考えられる。この観 点に立てば, 本論文で取り扱われている実験の諸条件 について, 多少疑問の感じられる点が認められた. 私 見では, 研究で対象とされた欠陷の大きさ・位置・波 動の入力条件と対象としている手法の対応がよくない ために，論点が明確とはならなかったと考えられた。 そこで, それらの点に関して打音法の定量化への道筋 を明確にしていただくべく，討議をお願いする.

\section{2.「打音法」の位置付けと用語について}

いわゆる超音波を用いた非破壊検査法は，20 世紀 になって発展を遂げ，コンクリート分野でも実用化及 び規格化が進められている。それらの研究成果によ り，コンクリートに何らかの擾乱を与えて，その折に 発生する弾性波を検出する検査法に「打音法」も属す ると整理されている ${ }^{1)}$ ただし，それぞれの研究者が 勝手な名称付けを行った結果として, Impact ${ }^{-}$ Response, Pitch-Catch, Sonic-Echo, ImpulseEcho など様々に呼ばれている.

最近では，アコースティック・エミッション (AE) センサの校正用として National Bureau of Standards : NBS (現在の National Institute of Standards and Testing : NIST) で開発された変位型センサを 用いて, 鋼球落下衝撃力によって発生した弾性波動を
検出する手法をCornell 大学の Sanslone 等が Impact-Echo ${ }^{2)}$ と新たに命名し, これが世界中で最も 著名となりつつある。しかし，これらは全て「弾性波 法」の中で外力を入力する能動型の試験法に属してい るにすぎない.著者等は本論文では「打音法」を Impact Acoustics と名付けられ, 人間の聴覚による 「打音検査」と区別されるとしている。しかし，これ は接触型と非接触型のセンサの違いに他ならず, むし ろ統一的な取り扱いと命名を考慮されるべきではない かと考える。

\section{3. 波動成分と物体寸法}

衝撃的な入力による弾性波動の発生・伝播と通過す る欠陥の位置及び形状との関係については, 既に多く の研究成果が蓄積されている. 理論的にもほぼ解明さ れており, 本質的な事項は, 発生した弾性波が伝播の 過程で共振現象を生じる。その場合に, 考慮すべき主 な要因は対象物の代表長さ $L$ と伝播速度及の関係で ある. 弾性波の伝播速度を $V$, 周波数を $f$ とすれば, 基本的に反射波が発生する場では，伝播経路長により 共振現象が発生し, 共振周波数は,

$$
f=V /(2 L)
$$

と導かれる。

本研究の実験で使用されている計測条件によれば,

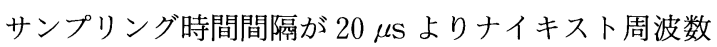
は $25 \mathrm{kHz}$ となり, 可聴音域を対象とされていること がわかる，その場合に，供試体の寸法程度 $(20 \mathrm{~cm} \times$ $60 \mathrm{~cm} \times 60 \mathrm{~cm}$ ) の代表長さが, 式( 1 )の対象となる ことは明らかである。それらは, 数 $\mathrm{kHz}$ から $20 \mathrm{kHz}$ となり,まさに測定対象周波数帯にあり, 研究対象に 対して供試体寸法は小さ過ぎたのではないかと危惧さ れる。

本研究で対象とされているのは, 表面部に存在する 欠陥 (空隙) であるので, 共振現象により抽出される 
べきは，欠陥の深さにる共振周波数，欠陷上部表層部 の板振動による共振周波数の 2 種類と考えられる. し かし，後者の周波数付近に供試体形状の影響が想定さ れ，前者はナイキスト周波数以上の周波数帯にあると 考えられるなど，かなり厳しい測定条件と考えられ る.

現実に，打音法が適用されている構造物は，トンネ ルライニングとか壁構造などであり，各段に大きな寸 法の部材内部に生じている小さな欠陥の検出であり， 本研究で提案された手法は，有用性が高いと考えられ る.ただし，式(1)の共振周波数が検出できるために は，本論文で検討されている通り入力周波数帯が，そ れを越える成分を含んでいることが必要条件であるこ とも考慮が必要である. 本論文では, 欠陷上部コンク リートの板振動のみが確認されたに留まっており，式 (1)による検討が不十分になっているのは残念であ る.さらには, 正しくは構造体の 3 次元物体としての 共振周波数が発生するために，検出波動のスペクトル 分析結果の評価も再検討が必要と思われる.

\section{4. 波動の 3 次元性}

本研究の新規性は, 実験に留まらず有限要素法 (FEM) 解析により数値的に波動伝播現象を解明して いる点が挙げられる.しかし，これについても今後の 研究動向への展開を考慮して討議をお願いする. 弾性 波動理論は，一般の弾性論からはかなり外れた理論と 言える. 例えば, 波動現象は理論的には変位解を求め ることになるため, 1 次元とか 2 次元で解いた場合に は, 解かれるべき変位が 1 次元的, 2 次元的に発生し ていることを仮定している。これは，静的場での解を 考えれば容易に理解できるように，2次元ならば奥行 き方向に全て同じ変位が発生していることを仮定した
ことになる．理論的には，動的解では奥行き方向に 3 次元解を積分した結果として 2 次元解が得られる. 1 次元はさらにもう 1 方向に積分した結果として導かれ る.これは，実際には問題を簡略化しているのではな く，非常に大胆に波動場を省略しているのである．そ の意味で, 1 次元とか 2 次元での解析結果は実験と合 致するかのような考え方には元々無理があると考えら れる. 本論文中の結果でも, 解釈に苦労されているこ とが明らかである。したがって, 本来は 3 次元解析が 望ましいが，2 次元であれば波動の経時的な挙動解明 以外に意義を持たせることは困難であると考えられ る.

\section{5. おわりに}

以上，論文の内容について質問と討議を御願いし た。本論文は，これまでにあまり注目されなかった波 動問題の重要性を打音法の実用化に関連して明示され た先駆的な成果の盛り込まれたよい研究であると考え ている.ただし，本討議で指摘させていただいた論点 と疑問は，多くの読者にも明確に認識されていないも のであると考え，貴重な成果における論点を明らかに 示していただくために討議を申し込んだものである. よろしく，ご討議をお願いする。

\section{参考文献}

1）コンクリート構造物の診断のための非破壊試験方法研究 委員会報告書, (社) 日本コンクリート工学協会, 2001 年 3 月.

2) Sansalone, M. and Streett, W. B., Impact-Echo: Nondestructive Evaluation of Concrete and Masonry, Bullbrier Press, Ithaca, NY, 1997.

(2002.10.7 受付)

回答者 $($ Closure $) \longrightarrow$ 鎌田敏郎・淺野雅則・国枝 稔・六郷恵哲 (岐皁大学)

Toshiro KAMADA, Masanori ASANO, Minoru KUNIEDA and Keitetsu ROKUGO

\section{1.はじめに}

討議の項目のそれぞれに対応した形で説明を行う。

大津氏からの討議には, 単に, 私共の論文に対する 討議にとどまらず，コンクリートへの弾性波法の適用 に関する研究に携わる者が考慮すべき共通の問題点が 示されており, 当該分野の今後の進展のために極めて 重要な論点が含まれている。この貴重な討議の場を与 えていただいたことに感謝するとともに，以下に回答 を述べる. なお, 回答では, 大津氏からの質問おょび

\section{2.「打音法」の位置付けについて}

ここでは，本論文において，マイクロフォンにより 弾性波を受振する手法を「打音法」と定義し, 接触型 振動センサを用いる弾性波法と区別した理由と, 手法 の命名の根拠について述べさせていただく.

まず，接触型振動センサにより弾性波を受振する場 
合は，一般的には，センサを，何らかの接触媒質を介 してコンクリート表面に直接接触させる。これに対し てマイクロフォンを用いる場合は，上述の接触媒質に 代わって空気が媒質となっており，対象物表面の振動 により生じる 2 次的な空気の振動を計測している。こ れらの違いから, 結果的には, 接触型センサではセン サの接触状態の影響が大きいのに対して，マイクロフ オンではこの影響は小さい。

また，接触型センサの場合は，センサの設置筒所の 違いにより受振波形が大きく異なることが予想され る.一方, マイクロフォンでは, 設置位置の違いが波 形特性に与える影響は（刘象物表面からの距離が音を 受振するために適切な範囲内にあれば）小さいものと 考えられる。

さらに，接触型センサによれば維波共振現象が捉兄 られるケースでも，マイクロフォンによってはこれを 把握することが困難であるなど, 適用上の限界も異な っている.これについての詳細は，次章で後述する。

このように，マイクロフォン受振と接触型センサに よる場合との特徴の違いは大きいものと判断してお り，両者を区別するのが妥当と考元る。また，広く一 般の読者に手法の原理等を理解して頂く上でも，両者 を区別した方が好都合ではないかと考えている.

「打音法」という和文名称の命名の根拠であるが， これは論文中でも示したとおり，(社)日本コンクリー 卜工学協会の「コンクリート構造物の診断のための非 破壊試験方法研究委員会」報告書における定義になら つたものである. 英文の Impact Acoustics について もこの報告書の記述にしたがったものであり，この用 語は，上記委員会で伊東の研究論文1)な゙を参考にし て命名したものである。

\section{3. 波動成分と物体寸法}

この項目における大津氏の討議の論点は，打音法に より得られた周波数分布の解积に抢ける緹波共振抢よ びたわみ共振現象の扱いと，この解釈を適切に行うた めに必要な供試体寸法の問題であると考えられる。そ こで，私共の既往の研究結果 ${ }^{2)}$ 基に考えを述べさせ ていただく.

写真-1に，実験に用いた供試体と，供試体内部の 久陥の配置状況を示す。供試体寸法は, 長さ $4 \mathrm{~m}$, 幅 $2 \mathrm{~m}$ ，厚さ $20 \mathrm{~cm}$ である。このような寸法としたこと により，打音法の適用にあたっては供試体自体の共振 や側面からの反射波の影響等はほとんどないものと考 光られる。また，供試体中には，空陌を模した円板状 の人工欠陥（厚さ $5 \mathrm{~mm}$ ）が埋設してある。なお，マ

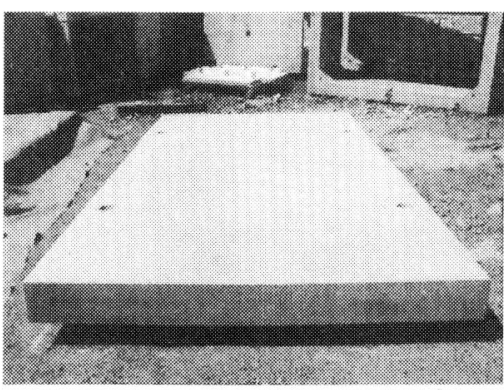

（a）床版供試体

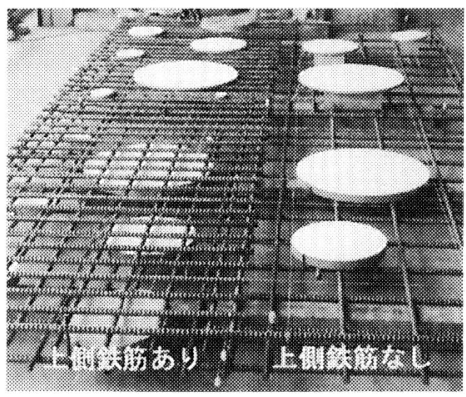

（b）供試体内部状況

写真-1 実験供試体の概要

イクロフォンによる打撃音の計測および加速度計によ る表面振動の測定を行っており，基本的には本論文に おける方法と同じである。

この実験では，弾性波計測条件として，式（1）から 算出される縦波共振周波数を考慮して, サンプリング 夕イムを $10 \mu \mathrm{s}$ （ナイキスト周波数： $50 \mathrm{kHz}$ ）とし た.

$$
f=\frac{V}{2 d}
$$

ここに, $f$ : 共振周波数 $(\mathrm{Hz}), V$ : 弾性波伝播速 度 $(\mathrm{m} / \mathrm{s}), d:$ 板厚 $(\mathrm{m})$ である。

この実験に扔けるコンクリートの弾性波伝播速度 は， $4500 \mathrm{~m} / \mathrm{s}$ であり，式(1)により計算すると板厚 $(20 \mathrm{~cm})$ に相当する縦波共振周波数は $11.25 \mathrm{kHz}$ で ある．また，この実験では， $\phi 9.53 \mathrm{~mm}$ の鋼球落下 により弾性波入力を行っている.したがってこの場合 の弾性波の上限周波数 ${ }^{3)}$ は, $30.5 \mathrm{kHz}$ と計算され, 上記の縱波共振周波数を把握するためには十分な実験 条件と考えられる。

図-1に，健全部（欠宿の埋設されていない筒所の 表面）に扔ける実験結果を，打撃音および表面振動の それぞれについて示す。この図によれば，表面振動で は図中に矢印で示す $11 \mathrm{kHz}$ 付近に明瞭なピークが出 現している．上述のとおり，これは供試体の板厚に相 当する緹波共振周波数とほほ一致して扔り，このピー 

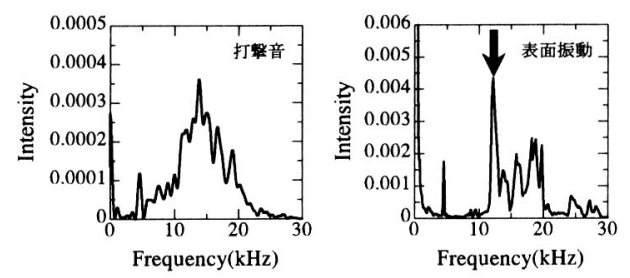

図-1＼cjkstart健全部の実験結果
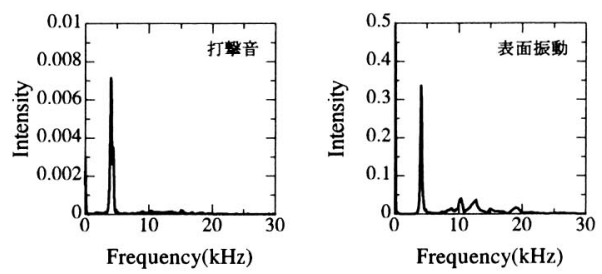

図-2 欠陷部の実験結果（直径 $20 \mathrm{~cm}$, 欠陥深さ $3 \mathrm{~cm}$ )

クは縦波共振現象によるものと考えられる。これに対

して打撃音では，このピークは確認できていない.

したがって，この実験のように，供試体寸法を本論 文の場合よりも十分大きくしても，結局，打撃音には 板厚に相当する縦波共振現象は含まれないことが明ら かとなっている。

次に, 供試体表面から深さ $3 \mathrm{~cm}$ のところに直径 20 $\mathrm{cm}$ の欠陥がある場合の実験結果を図-2に示す。これ によれば，打撃音と表面振動のいずれに扔いても 3.5 $\mathrm{kHz}$ 付近にたわみ共振現象に起因すると考元られる 明瞭なピークが出現している.

以上のように, 打撃音では, 供試体寸法を十分大き くしたとしてもたわみ共振によるピークであれば明確 に把握できるものの, 板厚や欠陷深さに相当する縦波 共振現象は感知されない.したがって, 本論文におい て縦波共振周波数が十分に把握できなかった理由が， すなわち，供試体寸法が小さすぎたことによるとは私 共は考えていない.

しかしながら，本論文での欠陷部に扔ける周波数分 布には，この実験結果とは異なり，たわみ共振による ピーク以外にも側面からの反射波に起因する成分を含 んでいるものと考えられ，論文中でこの点について十 分に言及していない部分については検討不足を認める ものである。

\section{4. 波動の 3 次元性}

私共も, 2 次元での解析における問題点については ご指摘のと抢りであると考えている。ただし，本論文

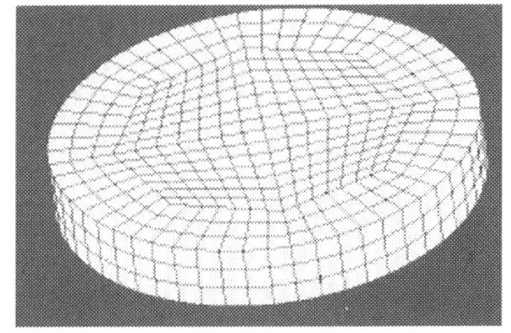

図-3解析モデル

の範囲においては, 受振波形の最大振幅值のみに着目 し, 最大振幅值と欠陥の大きさあるいは深さとの関係 の範囲内であれば 2 次元簡易モデルによっても把握が 可能であると考えて検討を行い，相応の結果を得るこ とができた。

しかしながら，私共も，例えば，受振波形の周波数 特性についての評価を目的とする場合には，2 次元モ デルでは不十分との認識を有しており，3 次元モデル を用いた検討も行っている ${ }^{4}$. この解析モデルでは, 欠陥上部コンクリート部を図-3に示すような円盤と 仮定している. 得られた結果より, 解析值は実験值と おおよそ良い相関を示すことが明らかとなっている。 ただし，この解析モデルでは円盤側面からの反射の影 響は無視されているため, 実験における現象を忠実に 再現するためにはこの影響を考慮する必要があるもの と考えられ，この点については，今後検討を加えてい く予定である.

なお，私共は，衝撃弾性波法による PC 部材のグラ ウ卜充填評価 ${ }^{5}$ や, 下水管路の劣化誩断 ${ }^{6}$ に 3 次元 FEM 解析を適用した検討も別途行っている.これら の結果においても解析と実験とは良好な対応を示して おり， 3 次元解析を行うことの有効性を確認してい る.

\section{5. おわりに}

本討議により, 打音法などの弾性波法における重要 課題について改めて考える機会を与えていただいたこ とに感謝する。この討議・回答が, 関心のある読者に とって何らかの研究上のヒントとなれば幸いである.

\section{参考文献}

1）伊東良浩：打音法によるコンクリート構造物の非破壊検 査に関する研究, 東京大学博士学位論文, 1997.6.

2）浅野雅則, 鎌田敏郎, 六郷恵哲, 遠藤友紀雄 : コンクリート 打撃音の周波数特性とその欠陷評価への適用，コンクリー 卜工学年次論文集, Vol. 24, No. 1, pp. 1545-1550, 2002,6. 
3) Sansalone, M. J. and Streett, W. B. : Impact Echo, Bullbrier Press, Ithaca, N. Y., 1997.

4）浅野雅則, 鎌田敏郎, 六郷恵哲, 児玉一郎：コンクリートの 欠陥評価における打撃音波形パラメータの役割, コンクリ 一ト工学年次論文集, Vol. 25, No. 1， pp. 1583-1588, 2003.7.

5）国枝泰祐, 鎌田敏郎, 浅野雅則, 六郷恵哲：PCグラウト充 填評価における弾性波パラメータの特性, コンクリート工
学年次論文集, Vol. 25, No. 1, pp. 1589-1594, 2003.7.

6）舟橋孝仁, 鎌田敏郎, 皆木卓士, 浅野雅則：コンクリート下 水管路の劣化診断における衝撃弾性波法の適用, コンクリ 一ト工学年次論文集, Vol. 25, No. 1， pp. 1625-1630, 2003.7.

(2003.5.23 受付) 